\title{
Religious Leaders as Agents of Peace and Security for Sustainable Development in Nigeria
}

\author{
Justina Nwazuni Osajie \\ http://dx.doi./org/10.4314/ujah.v21i4.15
}

\begin{abstract}
The paper explores the possibility of drawing on religious values and ethos through our religious leaders in solving societal problems militating against peace and security for sustainable development in the country. The paper looks at the security and peace which religion proffers by inculcation of moral. Religion regulates the conduct and behaviour of people in the society and preaches good virtues needed in the society. The researcher undertakes historical and critical interpretation of the phenomenon which have militated against meaningful peace and security of the nation. It discovers among other things that bribery and corruption, poor leadership, moral decadence, insecurity, religious crisis or insurgence among others contribute to the low pace of security and peace in the nation. It concludes by recommending that all religious leaders/groups should draw on the theosophical perspectives of religion in the country to ensure adequate peace and security for peaceful co-existence in order for the nation to actualize her dreams of sustainable development.
\end{abstract}

Keywords: Religion, Peace, Security, Leaders, Sustainable Development

\section{Introduction}

Development as one may see can only come in an environment where peace and security prevails. This is the reason many people always believe that development, peace and security work hand in hand. For this fact, it is said that any society or community that seek 
development must advocate and promote peace and security within its place. It is a well known fact that Nigeria today, has been rated as one of the most corrupt nations in the world where all sorts of crimes, violence and corruption have become the order of the day for sustainability of development. Nigerians today by the Western world and even co-Africans like South Africa associate and likened us with fraud and corruption. Nigerians are been looked upon as potential fraudsters and are specifically scrutinized and subjected to all manners of humiliation to the extent of killing them for offence not committed and denying them visa to study in their region. Hence Ojo [2003] accentuated that the country has been drained and her resources laid waste through years of misgovernance and economic intrigue, high level of fraud, mismanagement and soon. Human beings value peace and security for sustainability of development. Therefore, for peace and security to take place in the society, the role of the religious leaders have to be put in place by their support and identification with nation policies and programmes, especially using the pulpit in the churches and the minbar in the Mosques to mobilize and sensitize populace to become law abiding and carry out their civic responsibilities to the nation and other citizens.

Religious leaders in this context are referred to the three main religions in Nigeria, Islam, Christianity and African Traditional Religion (ATR). Religion is looked at as the oldest institution that makes an important contribution to the well-being of the society. It is a unifying feature in the society hence Okwueze (2003) cited Marx's definition of religion as "the opium of the mass". Since religion gives us hope, where it appears there is no hope, it therefore makes it possible for us to live hopefully of a better tomorrow simply because its teachings have relieved the pains we are encountering today.

To correct the anomalies that endangered the Nigeria nation of political unrest, corruption by political leaders, religious crisis, poverty, kidnapping, ritual killings, assassination, ethno-religious 
violence and so on, it therefore beholds on the religious leaders to come up with the truth in reshaping the society. Thus, Adetona (2017) the Head of Religious and peace studies, Lagos State University, in his talk said the task of maintaining peaceful co-existence and security is the role of religious leaders because the people believe they are grounded in the issues of the Lord. So, the religious leaders should be upright in their lives in other to correct the deviant leaders or citizens that are not of good behaviour.

The religious leaders should imitate their masters. Jesus Christ, Muhammed and Traditionalists as they all proffer peace of which where there is peace eventually security will reign. For example, Jesus in his era delivered the Israelites from their bondage. He gave them freedom. He did not separate religion, peace and security. Jesus Christ made it clear that his mission was to liberate those from captivity into freedom which is found in Luke 4:18-19. So many prophets of the Old equally did the same especially Amos whom God sent from Southern kingdom of Israel to the Northern kingdom warning them to deceased from their evil ways of perverting justice and oppression of the poor. The problem of moral decadence, corruption, poverty, disease and ignorance all call for Christian/Religious leaders' participation in politics. When godly people who have the fear of God are in position, peace will reign and the society will be at peace. The nation will be secured. The fear of God in them will aid them to rule according to God's directions and not to satisfy their self aggrandizement.

\section{Conceptual Clarification}

Religion: Religion is a difficult phenomenon to define. For the interest of this paper, religion according to King [2003], "intentionally offers beliefs moral codes and values from which a young person can build a personal belief system". This personal belief system enables the young person to build an identity. The living 
up to this expectation is the draw line for the struggle to live up to a standard of life worthy of this behaviour. Therefore, religion helps in the development of the society. The society made up of well, behaved individuals will no doubt experience a national peace which of course will lead to security and eventually lead also to the sustainable development.

Leaders: Leaders according to Longman dictionary (2005) is a person who leads a group of people especially the leader of an organization: Spiritual Leader: a good leader is one that have the interest of his followers at heart. In a pluralist society like Nigeria, it is the duty of leaders to create an atmosphere of unity in diversity, a unity that is not based on uniformity. According to Ekwunife [1995], "A good leader is importantly a conserver of human values. By values, we mean the worth which people generally place on certain outlook on life, moral and ethical actions, social behaviour, customs and laws for the organization of society".

Peace: According to David (2006), peace is defined as the absence of war, fear, conflict, anxiety, suffering and violence and about peaceful co-existence. Peace is primarily concerned with creating and maintaining a just order in the society and the resolution of conflict by non-violent means". This definition, is consonant with that of Rummel (1981) which regards peace as the absence of dissension, violence or war; a state of concord, harmony and tranquility. In line with this, Galtung (1996) states that peace is a state of absence of hostility, disturbance or agitation. From this, it implies that peace making invariably is associated with conflict resolution without the use of violence. Therefore, peace prevents loss of life and builds human capacity. 
Security: The word "Security" is difficult to define and has remained a contested idea. In other words, it has no universally accepted definition due to its many-sidedness arising from ideology and timeframe being addressed. Security according to Hornby (2005) posits things that are done in order to keep someone or something safe. Thus, security is protection from bad situations. Security by Terriff (1999) states it is about the protection and preservation from fear and danger that threatens the survival of Africa-Nigeria societies and peoples. Security is about survival and the conditions of human existence. It is about peace, development, and justice because the absence of all these create the conditions for conflict and insecurity. In the definition and conceptualization of security, one sees the inseparable and the important link between the two. Peace and security are these two sides of the same coin, one cannot live without the other and are mutually reinforcing. This is to say that the absence of one means the absence of the other and the existence of peace equally means the existence of security.

Sustainable Development: The idea of sustainable development is done to embrace the notion of making sure that the future generations inherit the land with support to their livelihood in such a way that they are not worse than generations of today [Atkinson, 1998]. One of the most famously and acceptable definition of sustainable development is the report given by Brundtland (1987) which the United Nations appointed the World Commission on Environment and Development (ECED) as "the development that meets the needs of the present without acknowledging the ability of future generations to meet their needs". This implies that sustainable development is about protection of the environment, economy and society. Therefore, for sustainability to have effect, peace and security plays a vital role and development is only sustainable if it is human oriented. 
Peace and Security Challenges: The Religious leaders who are the custodians of religion and morality with regard to the missionaries that brought Christian religion to Nigeria, made religious and moral education compulsory to all students which of course assisted in no small way in reduction of social vices and crime rate most especially in the decades of years before the mid seventies that Government taken over of schools started dwindling down of morals.

It is a known fact that among various works of government, it protects the lives and properties of the citizenry. These are to be protected and secured by all related government agencies like the police, army and other law enforcement agents. The large turn-out of University graduates without meaningful employment has aggravated the situation. This is the reason why in trend of time, there have been security challenges in different parts of the country such as kidnapping, ritual killings, yahoo, yahoo+, armed robbery cases, Fulani Herdsmen, fraudsters and other crimes of all type mentioned earlier. These graduates without moral education and fear of God will not have any respect for lives and properties. Therefore, becomes a problem to himself and the nation at large due to government lukewarm attitude towards moral instruction while in schools. Morality, according to Adukwu (2002) states that a morally conscious individual thinks better, acts better and is amendable to the dictates of conscience by living a worthy life in the society and refraining from such behaviour that may be considered a deviation from accepted societal norms and values. This is to say that an immoral being is a social as well as security risk to any nation. Hence, any little problem people are let loose with grievous effects of loss of lives and properties in almost all the states.

Poor leadership/ineffective leadership is another challenge to the peace and security in Nigeria as a result of corrupt practices among them. The general view of the Nigeria populace is that living standards have continued to dwindle rather than improve because of 
leadership. The confusion of greed for powers, fame and glory has made some leaders to cause havoc on the people and the society. As a matter of fact, the act of corruption is often, with the educated and the rich who capitalized on their status to create fear and insecurity among the less privileged people thereby exposing them to various temptations leading to corruption and other vices. On this note Omorogbe [1993] opines that injustice in any society results when the equals are treated unequally and the unequal are treated equally. Sequel to this, that state power is got, not to provide and care for the welfare of people but for their selfish interest. And corrupt behaviour and attitude in the management of state affairs have continued to rear its ugly head inspite of efforts put in place to minimize corruption through the setting up of some law enforcement agencies like EFCC and ICFC (Akinyemi, 2004).

Another threat to peace and security for sustainable development is insecurity. The problem of ethnic militants as well as religious/political intolerance has created so many crises in Nigeria. The negative activities of these sects such as Boko Haram, Militants in the Niger Delta, IPOB-Indigenous People of Biafra, Odua People's Congress (OPC), Arewa People's Congress (APC) etc has continue to undermine development efforts in the country by their violent disturbances, killing of people, bombing of individuals, government institutions and some media houses, markets etc. These nefarious acts propounded by these groups equally threatened the social and economic activities of the people by scaring investors thereby leading to under development in the country. Buttressing this Aghalor (2011) said that "Any country that cannot provide security for its citizens is sliding into anarchy and a situation where might is right".

Socio-economic condition is yet another factor that hinders peace and security for sustainable development in Nigeria. One of the elements that promote violent crimes in any nation is socio-economic order that gives widespread poverty and unemployment of youths 
(Nwosu, 2009). He also said that environment that creates a tiny minority in obscene wealth and large majority swimming in abject poverty and degradation cannot but be a breeding ground for illfeelings and suicidal instincts. Again, a socio-economic organization that has a great wide gulf between the have and the have nots cannot but sets nurturing ground for evil acts as envisaged in Nigeria Society today. Furthermore, a socio-economic order that promotes materialism as the primary values of the society no doubt fosters common of crime as it is with Nigeria Ekpeyong (n.d). This, however, any nation that operates socio-economic order that fosters wealth accumulation by the political class at the expense of equity, productivity, justice, fair play and respect for human rights of the people as well as rule of law must sooner or later be a source of violent and instability. If this done, there will be no peace and if no peace there will be no security for a sustainable development.

\section{The Role of Religious Leaders as Agents of peace and security for Sustainable Development}

The role of religious leaders as agents of peace and security for sustainable development cannot be under emphasized since religion itself is one of the cultural patterns of human society which helps to shape and reshape the society. "Religion serves as an agent of social justice and truth". No doubt today that our present day Nigeria social environment is vehemently suffering against foreign inspired cultural disease like bribery and corruption, bureaucracy and nepotism, denial of merited official promotions, authoritarians and arrogance in power, love of money, moral decadence as well as religious persecution, insecurity etc. Therefore, for the nation to be at peace and security consciousness for a sustainable development, the religious leaders have to tell the leaders the truth. This, they could diligently and courageously fight against the above mentioned ills though her teachings, prophetic proclamation and criticisms. 
Religious leaders are to advise Nigerian leaders at all levels to lead by example especially when they are deviating from law or distorting the law. For instance, in the Old Testament we see the prophets criticizing the capitalist and the extortionist tendencies of their own societies. A good example of this, are Amos and Hosea. These men were leaders who lived above shame as a result of the fear of God in their lives. Therefore, the religious leaders should not only be spiritual but also human. Both Christians and Muslims must learn to show love and concern for human Political problems as their masters did. Thus, Nigeria will be a peaceful humanly habitable society if our leaders will strive and show the fear of God in their leadership.

Religious leaders in order to make Nigeria society maintain a peaceful co-existence, they should always speak the truth with all and to all without fear or favour knowing full well that the society is faced with all sorts of immoral acts. Therefore, the religious leaders must not stand aloof when issues affecting the stability of the society are at stake especially looking the ways the leaders at the helms of affairs are accumulating wealth while their subject suffer. In essence, if the religious leaders and the people are truthful, they will be guided away from vices and acrimony. Thus, religious leaders must be on ground in order to protect human dignity, rights and values. The religious leaders must be the moral watch-dog of the country. The presence of them in the country serves as the conscience which is necessary for peace and security that leads to sustainable development.

Through the preaching of our religious leaders, the conduct and behaviour of the populace will be regulated by inculcating the moral virtues needed in the society. If the people adheres to the religious sermons preached by Christians and Muslim, pastors and clerics, the behaviour of the people will be modified positively by shunning corruption and immoral acts, thereby, ensuring transparency and accountability, creating of job opportunities, ensuring service 
delivery and by maintaining law and order, protection of lives and properties of all citizens. If these are fervently and properly put in place, we believe that Nigeria will maintain a high sense of peace and when there is peace, security must take its place thereby leading to sustainable development in the society.

In addition to religious leaders as agents of peace and security for sustainable development in Nigeria, African Traditional Religion [A.T.R] contributes to the sustainable development psychologically. Ogbannaya [2009] opines that a sense of security and assurance of help from the spirit of the ancestors which Africans - Nigerian believer serves as a protective shield against such evil forces as witches and wizard, epidemics, influenza etc which can disrupt individual and communal development. This is to say that when one is faced with the difficulties of life, and in times of suffering, a good number of persons fall back on their traditional religious cultural beliefs not minding their religious tenets as Christian or Muslim. When these challenges are over the people fall back to their religious believe, pretend as if there is nothing wrong in the believe of 'syncretism'.

\section{Conclusion:}

Religion is a potent tool for peace and it should be practicalised to overcome differences in order to bring about sustainable development. Religion teaches moral, reshape the society and brings happiness for its followers. In other words, religion helps man to have his ultimate as well as building good citizens who will be useful to themselves adequately by contributing immensely to the peace and security of the nation for sustainable development.

Religion states that all human beings are equal before God and takes every person as a special creation of God Okebukola, [2012]. Religion however, condemns corruption, dishonesty, injustice, kidnapping, disrespects to constituted authorities etc. 
Therefore, for good leadership in Nigeria, the religious leaders must strive to teach moral virtues in their places of worship. As inculcators of moral virtues, they should always speak the truth and take the task of maintaining peaceful co-existence because the people have so much trust in them that they are well grounded in the issues of God. Therefore, the true practice of the tenets of religions will build Nigeria for a better nation where peace, security and justice will reign.

Security as people say is of God according to Psalm 127:1 that says except the Lord watched the city the watch man, watched in vain. As people of Nigeria, a religious nation has important role to play both individually and collectively. To achieve peace and security in our nation, Nigeria needs a religiously minded leader whose intellect is well known to what is honest, right and just. Democracy which forms the bases for sustainable development in Nigeria cannot survive except we have men and women who are religiously bent at the helm of affairs. On this note that Odumuyiwa (2010) states that "Democracy and National survival will continue to elude Nigeria unless everybody in government carries the ideals of the religion into whatever he does". There is need to call for religious dialogue between the three main religions in the country since most crisis are caused by religious conflict. It should be centred on the agreement and disagreement of each religious group for avoidance of crisis that will bring in security that leads to sustainable development in the country where there is peace.

Finally, on governmental level, there must be political force to do away with social maladjustment in the society and to get rid of all sorts of immoral acts as seen by the people. If this is done, we know, we are moving towards the right direction of overcoming our evil habits, thus ensuring peace and security for sustainable development. 


\section{Recommendations}

- Religious leaders should always let their lives be exemplary to others by speaking the truth with all and to all without fear or favour.

- Religious leaders should call on the government to ensure the teaching of religions in schools to inculcate good morals in the minds of school children right from their formative years to higher institutions.

- Religious leaders should appeal to the conscience of the leaders to ensure that Nigeria Inter-Religious Council [NIREC] organizes lectures that promote religious tolerance.

- Religious leaders should be adequately involved in preaching against maltreatment of the citizens by our leaders.

- The pulpit in the churches and the minbar in the mosques should be effectively used in criticizing the ills in the society as prophets of the Old did.

- Religious leaders should let the leaders know that every evil practice perpetuated if not corrected will be punished by God. Therefore, people should deceased from evil ways to give peace and security chance for sustainable development.

- The religious leaders in Nigeria should do away with the gifts of money and position in government and show good examples to their subjects.

- Value system should be re-introduced in the country. It should be brought up in our families, educational system, leadership role and we should live our lives for good and to the glory of God.

\section{Justina Nwazuni Osajie}

Department of Christian Religious Studies justinanwazuniosajie@gmail.com 


\section{Reference}

Adetona, A. (2017). https://guardian, [issue] religious leaders as agents of peace development December, $20^{\text {th }}$.

Adukwu, A.I. (2002). The Challenges of Moral Decadence in Nigeria; Lagos: Highland.

Aghalor, I.W. (2011). Ika Weekly, Saturday, October 1, - October 8, (p:6)

Akinson, P. (1998). Sustainable Development http://en:Eikipedia.org/wiki/edu...lecon

Akinyemi, A.B. (2004). Corruption: A battle Nigeria must win. Lecture delivered at a workshop organized by the Foursquare Gospel Church, Lagos.

Brundtland Commission (1987). World Commission on Environment and Development. $\mathrm{Pg} 43$.

David, J.F. (2006). Peace and Conflict Studies: An African Overview of basic concepts in Introduction to Peace and Conflict Studies in West Africa. Ibadan: Spectrum Books Limited.

Ekpeyong, A.B. (nd). The Menace of Insecurity in Nigeria. Ibadan: Lucky Star.

Ekwunife, A.N.O. (1995). Spiritual Explosions: Reflections on Christian Lives and Practices in Nigerian: Context. Enugu: SNAAP PRESS LTD

Galtung, J. (1996). "Cultural Violence, Journal of Peace. Research 27:3, 1990, Peaceful means. London: Sage.

Hornby, A.S. (2005). Advanced Learners Dictionary of Current English. Oxford University.

Nwosu, A.N. (2009). Security Challenge a Bane to National Development. Ibadan: Sunshine.

Odumuyiwa, E.A. (2010). Democracy and National Survival in Christian Historical Perspective, in Religions: A Journal of the Nigerian Association for the study of Religions, Vol. 13 \& 14. 
Osajie: Religious Leaders as Agents of Peace and Security for Sustainable Development in Nigeria

Ojo, T. (2003). "Upsurge of Ethnic Violence in Nigeria: Causes and Remedies”.(A paper from Obasanjo Leadership Forum, Oyo Unit).

Okebukola, A.O.A (2012). "Religion and Good Governance Nigerian Experience" in Religion and Governance in Nigeria, edited by Ayantayo J.K. and others. Religion Studies Series, Vol. 4:3, Ibadan: university of Ibadan.

Okwueze, M.I. (2003). Ethics, religion and society. Nsukka Price Publishers.

Omorogbe, J.I. (1993). Ethics: A systematic and Historical study Lagos: Joja Education Research.

Pearson (2005). Longman Dictionary; Denmark: British Library Cata-Loging-in Publication Data;

Rummel, R.J. (1981). Understanding Conflict and War. Vol. 5, The just Peace, Beverly Hills, C.A. Sage Publication.

Terriff, T. (1999). Security studies Today. Cambridge: Polity. 